\title{
LABORATORY VALIDATION AND FIELD VERIFICATION OF SILICA GEL SAMPLING TUBE FOR MEASURING ETHYLENE OXIDE IN AIR
}

\author{
Chong Kian Wei ${ }^{1}$, Md. Sani Ibrahim ${ }^{2}$, Goh Teik Beng ${ }^{3}$ \\ ${ }^{1}$ Chemistry and Biology Division, School of Arts and Science, Tunku Abdul Rahman College, Jalan \\ Genting Kelang, Setapak, 53300 Kuala Lumpur, Malaysia \\ ${ }^{2}$ SaniChem Resources Sdn. Bhd., D/A Pusat Inkubator SIRIM, Bandar Baru Salak Tinggi, 43900 Sepang, \\ Selangor \\ ${ }^{3}$ The Drug Research Centre, Universiti Sains Malaysia, 11800 Minden, Penang, Malaysia.
}

\begin{abstract}
A sampling and analytical method for the measurement of ethylene oxide (EtO) level in air was developed. The procedure was based on the entrapment of ethylene oxide in an activated silica gel adsorbent inside a sampling tube. The ethylene oxide was desorbed by distilled water and the eluent was analyzed by gas chromatography with flame ionization detector. Parameters such as breakthrough volume, method detection limit, desorption efficiency and storage tests for 14 days in ambient temperature and refrigerator were determined. Field samplings were performed at two factories in Kulim and Pulau Pinang respectively, which use ethylene oxide gas as sterilization substance. The desorption efficiency of ethylene oxide from silica gel tube was determined to be $87.8 \%$ over concentration range of $0.2-4.0 \mathrm{ppm}$ in 3 liters of air sample. The method detection limit was determined to be $1.0 \mathrm{ppm}$ whereas the precision of procedure was $10.7 \%$. All the parameters were shown to be meeting OSHA requirements.
\end{abstract}

\begin{abstract}
ABSTRAK Satu kaedah persampelan dan analisis untuk mengukur tahap etilena oksida dalam udara telah dibangunkan. Prosedur ini berasaskan pemerangkapan etilena oksida dalam penjerap gel silika yang telah diaktifkan dalam suatu tiub persampelan. Etilena oksida telah didejerap dengan menggunakan air suling dan eluen tersebut dianalisis dengan gas kromatografi yang dielengkapi dengan pengesan pengionan nyala. Parameter seperti keberkesanan pendejerapan etilena oksida daripada tiub silika, isipadu penembusan, had pengesanan kaedah, keberkesanan pendejerapan dan ujian penyimpanan selama 14 hari pada suhu ambien $\left(27^{\circ} \mathrm{C}\right)$ dan suhu peti sejuk $\left(4^{0} \mathrm{C}\right)$ telah ditentukan. Persampelan lapangan telah dilakukan di dua buah kilang masing-masing di kulim dan Penang yang menggunakan etilena oksida sebagai bahan pensterilan. Keberkesanan pendejerapan etilena dioksida daripada tiub gel silica telah ditentukan sebagai $87.8 \%$ pada julat kepekatan 0.2-4.0 ppm untuk tiga liter sampel udara. Had pengesanan kaedah telah ditentukan sebagai $1.0 \mathrm{ppm}$ manakala kejituan prosedur adalah $10.7 \%$. Semua parameter yang dikaji menunjukkannya memenuhi syarat OSHA.
\end{abstract}

(Keywords: Indoor air pollution monitoring, ethylene oxide (EtO), desorption efficiency, breakthrough volume)

\section{INTRODUCTION}

Ethylene oxide is widely used as a sterilant in the medicinal field [1] especially for heat-sensitive surgical tools and equipment [2]. It is also used as a chemical intermediate in the production of mono-, di-, and triethylene glycols; mono-, di-, and triethylene glycol ethers, ethanolamines; surface active agents and other chemicals [3]. In 1979, preliminary results of a long term carcinogenicity assay in mice were reported. In addition, an investigation of leukemia among workers potentially exposed to ethylene oxide in the Swedish factory was also reported [4]. Ethylene oxide was found to cause an increase in incidences of mononuclear cell leukemia and peritoneal mesothelioma in the rats [5]. Ethylene oxide can chemically bond with deoxyribonucleic acid(DNA) [4] to form N-7-(2hydroxiethyl) guanine [6], which is unstable and subsequently induces depurination in the nucleotic series [7]. Ethylene oxide exposure causes mutations, increases the rate of chromosomal aberration, sister chromatid exchange and other undesirable changes in the DNA of the mammalian cells [8]. The OSHA recommended exposure limit (REL) for ethylene oxide is $0.1 \mathrm{ppm}$ as an 8-hour time-weighted average (TWA) with 10-minute ceiling limit of 5 ppm whereas the OSHA permissible exposure 
limit (PEL) is $1 \mathrm{ppm}$ as an 8-hour TWA with a 15-minute excursion limit of 5 ppm [9]. Many methods have been developed to monitor ethylene oxide in air such as charcoal tube [10], $\mathrm{HBr}$ coated charcoal tube [11], Tedlar gas bag [12], impinger [3], badge [13], 3M charcoal disc [14] passive dosimeter [15] and direct reading with IR, photoionization detector and chromatographic gas [3], gas sensor [16] and also bio-monitoring [6,17].

However, all these methods have their advantages and disadvantages such as sampling and analysis costs, sampling duration and interference. In this study, recoveries of ethylene oxide from silica gel and charcoal tubes were determined and type of adsorbent which gives higher percentage of recovery was selected to continue the validation tests. Objectives of this study were to develop a new method which is cheaper, shorter in analysis and sampling time as well as able to fulfill all the OSHA accuracy and precision requirements.

\section{EXPERIMENTAL}

\section{Materials and Reagents}

Silica gel powder $(60-120$ mesh $)$ and coconut shell charcoal (35 - 50 mesh) were purchased from BHD Chemicals Ltd. (England) and E. Merck (Germany) respectively. Both adsorbents were activated at $110{ }^{0} \mathrm{C}$ for $24 \mathrm{hr}$ before used. Ethylene oxide (EtO) with a purity of more than 99.8\% was purchased from Fluka ChemikaBiochemika Company (Switzerland). The sampling tube was prepared by adding $1.000 \pm$ $0.005 \mathrm{~g}$ of activated adsorbent into $120 \times 6 \mathrm{~mm}$ i.d. glass tube. Glass wool was plugged at both open ends of the tube to hold the adsorbent in place. Rubber septa were used to cap both open ends of the tube to prevent deactivation of the adsorbent due to the atmospheric humidity. All prepared sampling tubes were kept in a desiccator before used. Ethylene oxide stock standard solution was prepared by bubbling ethylene oxide gas into approximately $50 \mathrm{~mL}$ of water in a $100 \mathrm{~mL}$ volumetric flask. The lower concentration of ethylene oxide standard solution was prepared by diluting from the stock standard solution to the desired concentration with distilled water.

\section{Apparatus and Conditions}

Air sample was collected by connecting the sampling tube to a BUCK S.S personal air sampling pump (A.P. Buck Inc) [18]. The flow rate of the pump was calibrated daily before use. The content of the ethylene oxide in the eluent samples were analyzed by Shimadzu 9A gas chromatograph (Japan) equipped with flame ionization detector and Hitachi D-2500 Chromato-Integrator (Japan). A $2 \mathrm{~m}$ x $0.3 \mathrm{~mm}$ i.d. glass column packed with $3 \%$ Carbowax(polyethylene glycol) succinate on Chromosorb W-HP (80/100 mesh) was used for the separation of ethylene oxide from other air components. The oven temperature was programmed at $50{ }^{0} \mathrm{C}$ for the first 2 minutes and then ramped at $100{ }^{0} \mathrm{C} / \mathrm{min}$ to $120{ }^{0} \mathrm{C}$ for 2 minutes. Inlet and detector temperatures were $230{ }^{0} \mathrm{C}$. Nitrogen was used as carrier gas and the flow rate was $50 \mathrm{~mL} / \mathrm{min}$. Test atmosphere, which was used to determine breakthrough volume of the sampling tube was prepared by bubbling $2 \mathrm{ml}$ of ethylene oxide solution in an enclosed impinger tube connected to a 1 liter round flask using purified nitrogen gas. The concentration of the ethylene oxide in the $2 \mathrm{~mL}$ solution was equivalent to $150-170 \mathrm{ppm}$ for 3 liters of air sample. Relative humidity of the test atmosphere inside the flask was determined by the volume of water that has been evaporated from the $2 \mathrm{~mL}$ ethylene oxide solution during the bubbling process.

\section{Breakthrough Volume}

The breakthrough volume of the sampling tube was determined by drawing air with flow rate at $150 \mathrm{~mL} / \mathrm{min}$ from the test atmosphere prepared in a 1 liter round flask through two sampling tubes which were connected in series. The second sampling tube, which acts as backup tube was changed after every 1 liter of air has been drawn through both sampling tubes. Adsorbed ethylene oxide in the backup tube was eluted with distilled water and the eluent was analyzed by gas chromatograph with flame ionization detector. This test was repeated twice to ensure reproducibility.

\section{Method Detection Limit}

Method detection limit was determined from a set of recovery data obtained from a series of liquid spiked sampling tubes. The spiked concentration was equivalent to $0.1-2.0 \mathrm{ppm}$ in 3 liters air samples. Method detection limit was calculated by the following equation, which was obtained from OSHA: Method Evaluation Guidelines [19]. 
$\mathrm{MDL}=3(\mathrm{SEE} / \mathrm{A})$

Where SEE is the standard error of estimate for the regression curve which obtained from a plot of chromatographic response versus amount of recovery. $\mathrm{A}$ is the analytical sensitivity (slope).

\section{Desorption Efficiency}

The desorption efficiency of ethylene oxide from the sampling tube was determined by spiking with an equivalent weight of ethylene oxide in distilled water $(2 \mu \mathrm{L})$ into the sampling tube. The concentrations of ethylene oxide which were spiked into the sampling tubes were equivalent to $0.2,1.0,2.0$ and $4.0 \mathrm{ppm}$ in 3 liters air sample. Each concentration was repeated for six times. Spiked sampling tubes were stored in the dark at room temperature overnight. Spiked ethylene oxide was eluted with $10 \mathrm{~mL}$ of distilled water and the recovered amount of ethylene oxide in the eluent was determined using GC-FID. Similar procedure was used to determine the desorption efficiency of ethylene oxide from coconut shell charcoal sampling tube.

\section{Stability Test}

Forty-five sampling tubes which contained amount of ethylene oxide equivalent to $2 \mathrm{ppm}$ ethylene oxide for 3 liters air samples were prepared by spiking $50 \mu \mathrm{L}$ ethylene oxide solution into each tubes. Three tubes were eluted on the same day after spiking. The other twenty one tubes were kept at $5{ }^{0} \mathrm{C}$ in a refrigerator and the other twenty one tubes were kept in dark condition inside a drawer at room temperature. On every other day within 14 days, three tubes from each group were eluted by $10 \mathrm{~mL}$ of distilled water and the amount of recovered ethylene oxide in each tube was determined using GC-FID. An ethylene oxide solution was also tested for stability within 14 days in a refrigerator. Precision of overall procedure at $95 \%$ confidence level was equivalent to \pm $1.96 \mathrm{SEE}$ by assuming a normal distribution of the values about the storage tests regression curve and uniformity of the entire range of the curve. SEE is the total standard error of the overall procedure for each storage test including the personal air sampling pump variability (SP). Precision of overall procedure was calculated by the following mathematical equation [19].

$$
\mathrm{SEE}=\left[\left(\mathrm{SEE}_{\mathrm{R}}\right)^{2}+(\mathrm{SP})^{2}\right]^{1 / 2}
$$

Where $\mathrm{SEE}_{\mathrm{R}}$ is the standard error of estimate for the regression curve of each storage test.

\section{Field Sampling}

Simple random field samplings were carried out in two factories which used ethylene oxide as a sterilization substance for their products in Kulim Industrial Area, Kedah and Bayan Lepas Free Industrial Zone, Pulau Pinang. Air samples adjacent to the sterilization chamber were collected by drawing 3 liters of air through the sampling tubes using $150 \mathrm{~mL} / \mathrm{min}$ flow rate. The open ends of the sampling tubes after sampling were sealed with aluminium foil and capped with rubber septum before transported in a thermostat box containing blue ice to the laboratory for analysis. All the sampling tubes were kept in a refrigerator before analysis. The obtained field sampling results were used to calculate time weighted average by using the following mathematical equation $[20,21]$.

$\mathrm{TWA}=\Sigma \mathrm{x}_{\mathrm{i}} \mathrm{t}_{\mathrm{i}} / \Sigma \mathrm{t}_{\mathrm{i}}$

Where $x_{i}$ is the concentration of the ith air sample and $t_{i}$ is the averaging time of the ith air sample. The obtained TWA results were further converted to 8-hr TWA. Locations of the sampling site in MM and BB factories are shown in the table 1.

Table 1: Locations of the sampling site in MM and BB factories.

\begin{tabular}{|l|c|l|c|}
\hline MM factory & $\begin{array}{c}\text { Sampling } \\
\text { sites }\end{array}$ & BB factory & Sampling sites \\
\hline Awaiting Sterilization Area & $\mathrm{a} \mathrm{\&} \mathrm{b}$ & Awaiting Sterilization Area 1 \& 2 & A \& B \\
\hline Degassing Area & $\mathrm{c} \& \mathrm{~d}$ & Control Room 1 \& 2 & $\mathrm{C} \& \mathrm{D}$ \\
\hline Quarantine Area & $\mathrm{e} \mathrm{\&} \mathrm{f}$ & Degassing Area & E \& F \\
\hline Packaging Area & $\mathrm{g}$ & Operator Room & $\mathrm{G}$ \\
\hline Incineration Room & $\mathrm{h}$ & Loading Area & H \& I \\
\hline EtO Gas Tank Room & $\mathrm{I}$ & Outside Factory & $\mathrm{J} \& \mathrm{~K}$ \\
\hline Loading Area & $\mathrm{j}$ & Quarantine Area 1 \& 2 & L \& M \\
\hline
\end{tabular}

Note: MM represents the factory situated in Kulim industrial area, Kedah and BB represents the one situated in Bayan Lepas Free Industrial Zone, Pulau Pinang. 


\section{RESULTS AND DISCUSSION}

As shown in Table 2, the recoveries of ethylene oxide from silica gel tubes (average $83.9 \pm 2.8 \%$ ) were higher than the recoveries obtained from charcoal tubes (average $17.1 \pm 4.2 \%$ ). The low recovery shown by charcoal tubes may be due to their high surface activity and strong adsorptive behavior which may induced chemical reactions during storage and desorption of the samples [22]. Based on these results, silica gel sampling tube was selected to continue the following validation tests due to the obtained high recovery.

Table 2: Percentage recovery of ethylene oxide from silica gel and coconut shell charcoal sampling tubes

\begin{tabular}{cccc}
\hline No.silica gel tubes & \% recovery & No. charcoal tubes & \% recovery \\
\hline 1 & $85.9 \pm 2.6$ & 1 & $19.6 \pm 0.9$ \\
2 & $87.3 \pm 4.3$ & 2 & $21.1 \pm 0.6$ \\
3 & $83.6 \pm 1.1$ & 3 & $21.4 \pm 0.2$ \\
4 & $80.0 \pm 08$ & 4 & $11.6 \pm 2.3$ \\
5 & $81.4 \pm 3.3$ & 5 & $13.5 \pm 2.6$ \\
6 & $85.1 \pm 1.2$ & 6 & $15.6 \pm 1.4$ \\
\hline Mean & $83.9 \pm 2.8$ & Mean & $17.1 \pm 4.2$ \\
\hline
\end{tabular}

The method detection limit which was determined by a set of recovery data from a series of ethylene oxide solution spiked standards is $0.583 \mu \mathrm{g}$ in $3 \mu \mathrm{L}$, which is equivalent to $0.11 \mathrm{ppm}$ in 3 liters air sample at ambient condition. The mean desorption efficiency for ethylene oxide over the concentration range of $0.2-4.0 \mathrm{ppm}$ is $87.8 \pm$
3.6\% (Table 3). The obtained mean desorption efficiency fulfils the OSHA standard requirements, which is more than $75 \%$ [19]. The bias of the desorption efficiency result is found to meet EPA QA/QC protocols bias for spike recovery which is $\pm 25 \%$ [22]. The obtained desorption efficiency result is used as correction factor to field sampling test results.

Table 3: Recovery of ethylene oxide from silica gel sampling tubes at various spiked concentrations

\begin{tabular}{llcll}
\hline $\begin{array}{l}\text { concentration } \\
\text { (for 3 liters air sample) }\end{array}$ & 0.2 & 1.0 & 2.0 & 4.0 \\
\hline \% recovery(desorption efficiency) & $80.8 \pm 4.1$ & $80.7 \pm 2.4$ & $89.8 \pm 2.5$ & $91.0 \pm 2.0$ \\
& $81.9 \pm 8.7$ & $90.6 \pm 4.3$ & $94.1 \pm 3.3$ & $90.9 \pm 1.3$ \\
& $81.3 \pm 9.4$ & $86.1 \pm 9.2$ & $95.7 \pm 2.8$ & $87.8 \pm 1.9$ \\
& $84.1 \pm 9.4$ & $87.6 \pm 5.0$ & $99.5 \pm 9.4$ & $83.9 \pm 2.0$ \\
& $84.1 \pm 7.2$ & $87.2 \pm 3.9$ & $98.1 \pm 3.3$ & $83.2 \pm 1.5$ \\
& $90.7 \pm 2.0$ & $75.0 \pm 4.1$ & $100.5 \pm 7.1$ & $81.9 \pm 3.0$ \\
Mean & & & & \\
Standard Deviation & 83.8 & 84.5 & 96.3 & 86.5 \\
Relative Standard Deviation & 3.6510 & 5.7141 & 4.0021 & 4.0159 \\
Combine Standard Deviation & 4.3559 & 6.7596 & 4.1566 & 4.6453 \\
Average \% recovery & 3.6084 & & & \\
Accuracy(\%) & 87.8 & & & \\
\hline
\end{tabular}

According to Figure 1, the breakthrough volumes for the first and second run are approximately 17 and 18 liters. The breakthrough is considered has occurred when the amount of ethylene oxide detected in the second sampling tube exceeds $0.10 \%$ of the total ethylene oxide prepared in the 1 liter round flask.
The relative humidity of the test atmosphere inside the 1 liter round flask was approximately $88.2 \%$ at $28{ }^{\circ} \mathrm{C}$, which fulfils OSHA's test atmosphere conditions that are approximately $80 \%$ at $22.2{ }^{\circ} \mathrm{C}$ [23]. This relative humidity is also quite similar to the atmospheric relative humidity in Malaysia that is $94 \%$ on a sunny day 


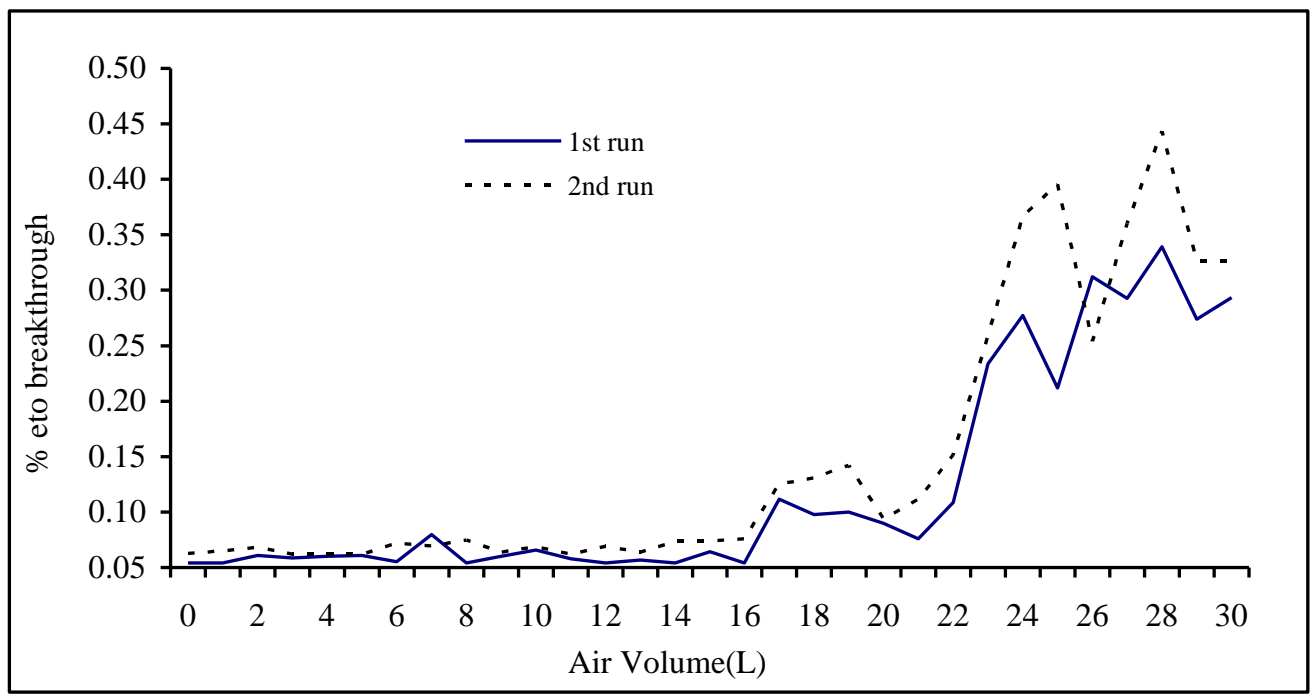

Figure 1: Determination of breakthrough volume.

[24]. After 30 liters air sample has been drawn through the sampling tubes, amount of ethylene oxide that has adsorbed in the first sampling tube is $74.8 \%$ in the first run and $63.5 \%$ in the second run based on the total ethylene oxide prepared in the 1 liter round flask. This shows that silica gel sampling tube is able to adsorb ethylene oxide up to these values before breakthrough occurs.
Silica gel sampling tubes which were spiked with ethylene oxide equivalent to $2 \mathrm{ppm}$ in 3 liters air sample can be stored up to 14 days in the refrigerator and 2 days at ambient temperature (Figure 2). Recovery of ethylene oxide from the sampling tubes after 14 days storage in a refrigerator and ambient temperature were $83.9 \%$ and $21.8 \%$, respectively (Figure 2).

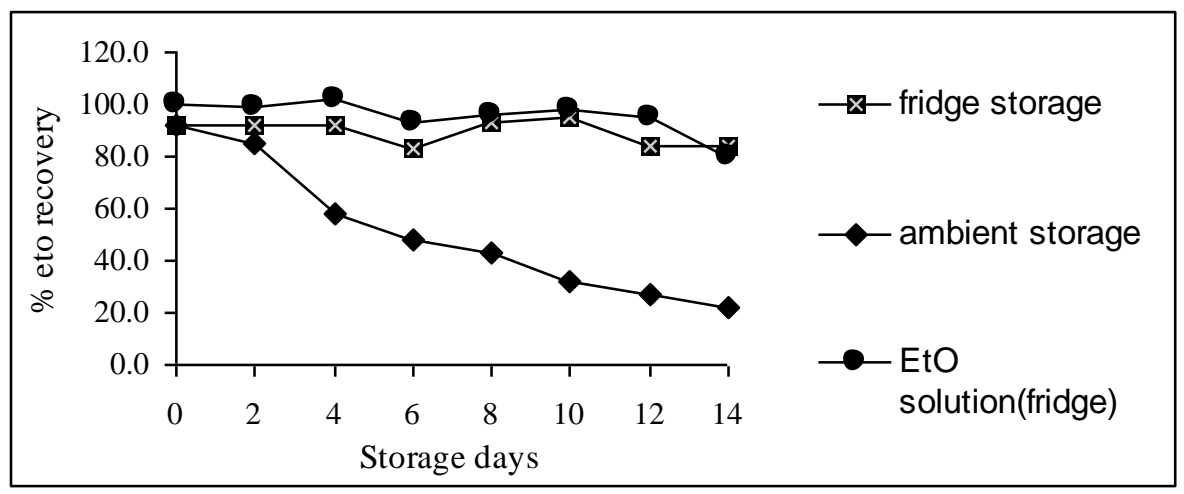

Figure 2: Stability test of ethylene oxide (EtO) in the silica gel sampling tube at room and fridge temperatures.

Low recovery obtained in the 14 days ambient storage test may be due to the high surface activity of silica gel which induces chemical reactions during storage [22]. Results obtained in the refrigerator storage test fulfils OSHA requirements [19], that the recovery (uncorrected for desorption efficiency) must be above $75 \%$ after storage and a change in recovery of more than $10 \%$ in 15 days storage was a significant uncorrectable bias and must be avoided. Amount of ethylene oxide in aqueous solution still remained at $90 \%$ after 12 days storage in a refrigerator at about $5{ }^{\circ} \mathrm{C}$ (Figure 2).

The precision of overall procedure at $95 \%$ confidence level for 14 days refrigerator and ambient storage test are $\pm 10.7 \%$ and $\pm 15.1 \%$, respectively. $\pm 3 \%$ of the sampling or pumping error [18] is included in this calculation. The obtained results are less than $\pm 25 \%$ at $95 \%$ confidence level which is stipulated by OSHA [19]. 
As shown in Figure 3a, ethylene oxide was detected in awaiting sterilization area and degassing area in MM factory in the first sampling event. The detected ethylene oxide concentrations are $0.54,0.40$ and $0.10 \mathrm{ppm}$, respectively. Ethylene oxide was detected in degassing area, quarantine area and outside the factory in the second sampling event with the concentrations at $0.51,0.41,0.15$ and $0.12 \mathrm{ppm}$ (Figure 3a).

Figure 3: (a) Ethylene oxide (EtO) concentration (ppm) in the MM factory, (b) Ethylene oxide (EtO) concentration in BB factory

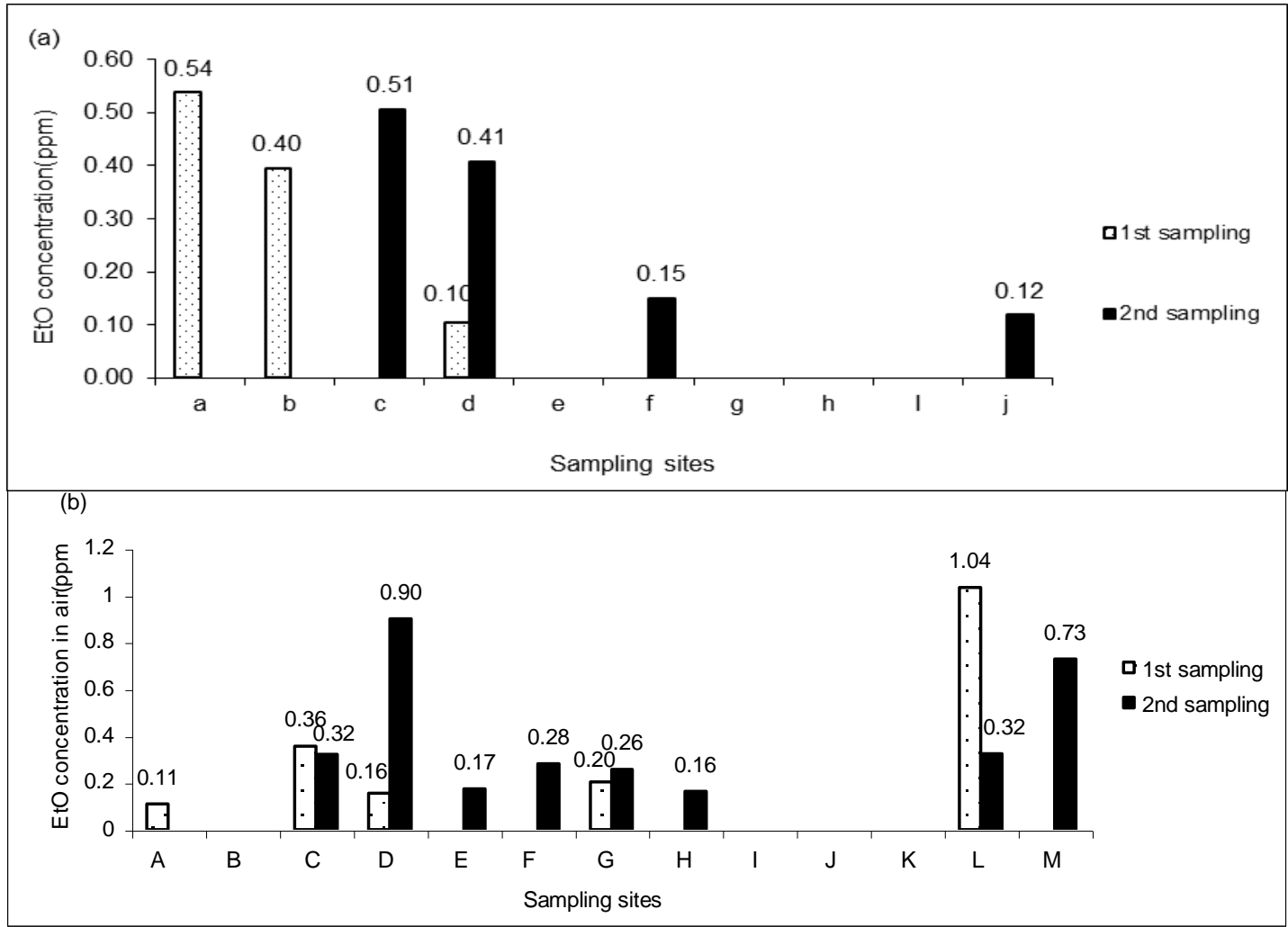

Note: Bars did not show in graph for sampling sites where no ethylene oxide was detected (lower than method detection limit).

Ethylene oxide was detected in awaiting sterilization area 1 , control room 1 and 2, operator room and quarantine area 1 and 2 in $\mathrm{BB}$ factory in the first sampling event. The detected concentrations are $0.11,0.36,0.16,0.20$ and 1.04 ppm, respectively (Figure $\mathbf{3 b}$ ); whereas in the second sampling event, ethylene oxide was detected in control room 1 and 2, degassing area, operator room, unloading area 1 and quarantine area 1 and 2 with concentrations ranging from $0.16-0.90$ ppm (Figure 3b).

The detected levels of ethylene oxide in factories $\mathrm{MM}$ and $\mathrm{BB}$ are below OSHA excursion limit (5 ppm for $15 \mathrm{~min}$ ) and NIOSH ceiling limit (5 ppm for $10 \mathrm{~min}$ ). The calculated 8 hour time weighted averages of the ethylene oxide level in MM factory are 0.05 and zero ppm in the first and second sampling events respectively; whereas in $\mathrm{BB}$ factory are $0.08 \mathrm{ppm}$ and 0.12 ppm in the first and second sampling events. All of the calculated 8 hour time weighted averages are below OSHA permissible exposure limit (PEL) and action level that are $1 \mathrm{ppm}$ and 0.5 ppm [9]. However, the calculated 8 hour time weighted averages of the ethylene oxide level in BB factory in the second sampling event is above the NIOSH recommended exposure limit (REL) that is $0.1 \mathrm{ppm}$ [9]. Therefore, BB factory may require further monitoring to ensure the concentration of ethylene oxide in the air surrounding the sterilization chamber is below 
the NIOSH's REL. However, ethylene oxide in the air surrounding the sterilization chamber in both factories is considered safe if OSHA regulations are imposed.

As shown in Figure 4, the concentration of ethylene oxide in BB factory increases obviously from 1300 to 1530 in the first sampling event and from 1140 to 1338 in the second sampling event.

This is due to the ethylene oxide was released from sterilization chamber when treated products were unloaded from the chamber. Besides, ethylene oxide can also be released from the treated products after unloading from the chamber [3]. According to OSHA substance safety data sheet for ethylene oxide [25], workers who carry out the unloading task need to wear oxygen mask to protect them from exposing to ethylene oxide gas. Similar results were obtained by a team of researchers in the measurement of ethylene oxide at one of medical sterilization sites in Japan [26].

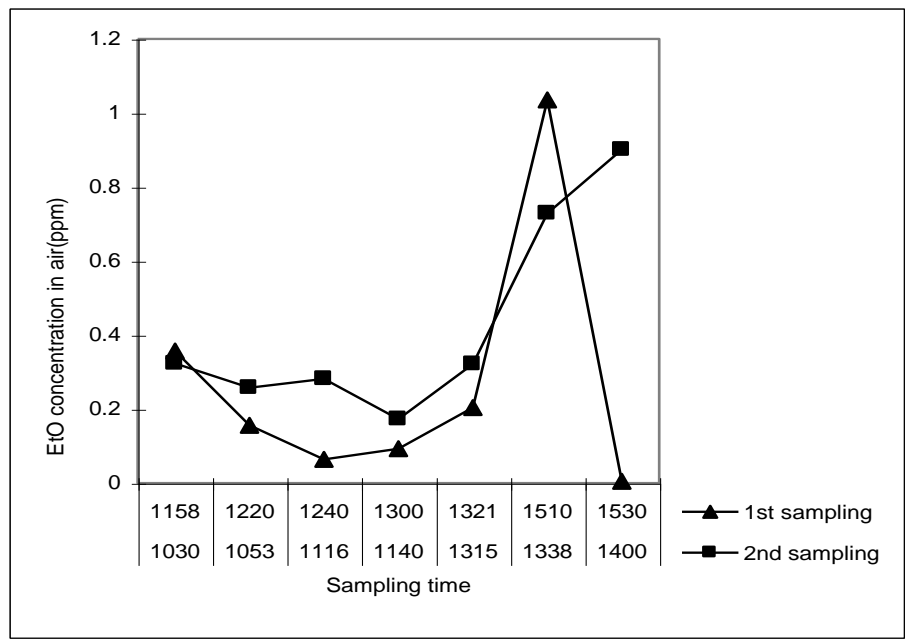

Figure 4: Ethylene oxide (EtO) concentrations in BB factory throughout the sampling time.

\section{CONCLUSION}

In conclusion, an accurate and precise method with cheaper cost and shorter analysis and sampling time was developed in this study. In this method, water was used as a solvent to extract ethylene oxide from the sampling tube. This is because water is a cheaper solvent and less toxic compared with other organic solvents such as carbon disulfide, benzene and dimethylformamide, which were used to extract ethylene oxide and 2-bromoethanol from the charcoal tube in $\mathrm{HBr}$ coated charcoal methods $[10,11]$. Furthermore, no solvent peak is produced during the analysis of sample with GCFID. Therefore, time per analysis can be shortened compared to other methods which use dimethylformamide, carbon disulfide and benzene as solvent.

\section{ACKNOWLEDGEMENTS}

We thank to the MM and BB company managers to allow us to collect the air samples in their factory. This project is financially supported by Universiti Sains Malaysia.

\section{REFERENCES}

1. Romano, S. J. and Renner, J. A. (1975). Comparison of Analytical Methods for Residual Ethylene Oxide Analysis, J. Pharm. Sci. 64(8):1412-1417.

2. Linda, L. N. (1994). Reviewer Guidance Validation of Chromatographic Methods. U.S.A.: Center for Drug Evaluation and Research (CDER), pp. 12

3. U.S. EPA. (1986). Locating and Estimating Air Emissions from Sources of Etylene 
Oxide. North Carolina: Office of Air and Radiation \& Office of Air Quality Planning and Standards.EPA-450/4-84-007L, pp. 10, $11,62-66$

4. NIOSH, (1981). Ethylene Oxide (EtO): Evidence of Carcinogenicity. Pubilcation No. 35 Cincinnati: National Institute for Occupational Safety and Health.

5. Potter, W. D. (1981). OSHA Evaluated Method: Ethylene Oxide. Salt Lake City, Utah.Organic Solventd Branch, OSHA Analytical Laboratory. (Organic Method\#30)

6. Segerback, D. (1990). Reaction products in hemoglobin and DNA after in vitro treatment with ethylene oxide and $\mathrm{N}-(2-$ hydroxyethyl)-N-nitrosourea.

Carcinogenesis. 11(2):307-312.

7. Strickberger, M. W. (1976). Genetics. 4th edn. Macmillan Company, Ontario :New York \& Collier-Macmillann Canada, Ltd, pp. 556-558.

8. Cummins, K. J. (1985). OSHA Evaluated Method: Ethylene Oxide. Utah: Organic Methods Evaluation Branch, OSHA Analytical Laboratory. (Organic Method\#50), pp. 6.

9. NIOSH. (2000). Preventing Worker Injuries and Deaths from Explosions in Industrial Ethylene Oxide Sterilization Facilities. Publication No. 2000-2119 Cincinnati: National Institute for Occupational Safety and Health.

10. Puskar, M. A., Nowak, J. L. and Hecker, L. H. (1988) Laboratory and field validation of JXC charcoal sampling and analytical method for monitoring short-term exposures to ethylene oxide. Am. Ind. Hyg. Assoc. J. 49(5): 237-243.

11. Cummins, K. J., Schultz, G. R., Lee, J. S., Nelson, J. H. and Reading, J. C. (1987) The development and evaluation of a hydrobromic acid-coated sampling tube for measuring occupational exposures to ethylene oxide. Am. Ind. Hyg. Assoc. 48(6): 563-573.
12. Puskar, M. A., Szopinski, F. G. and Hecker, L. H. (1991). Development and validation of a protocol for field validation of passive dosimeters for ethylene oxide excursion limit monitoring. Am. Ind. Hyg. Assoc. J. 52(4): 145-150.

13. Kring, E. V., Damrell, D. J., Basilio, Jr. A. N., McGibney, P. D., Douglas, J. J., Henry, T. J. and Ansul, G. R. (1984). Laboratory validation and field verification of a new passive air monitoring badge for sampling ethylene oxide in air. Am. Ind. Hyg. Assoc. J. 45(10): 697-707.

14. Mullins, H. E. (1985). Sub-part-per-million diffusional sampling for ethylene oxide with the 3M\#3550 ethylene oxide monitor. Am. Ind. Hyg. Assoc. J. 46(10): 625-631.

15. Gonzalez, L. A. and Sefton, M. V. (1985). Laboratory evaluation of stain-length passive dosimeters for monitoring of vinyl chloride and ethylene oxide. Am. Ind. Hyg. Assoc. J. 46(10): 591-598.

16. Hodgson, A. W., Jacquinot, P. and Hauser, P. C. (2000). Amperometric sensing of the ethylene oxide in the gas phase. Anal Chem 72(10): 2206-2210.

17. Tates, A. D., Boogaard, P. J, Darroudi, F. A., Natarajan, T., Caubo, M. E. and Van Sittert, N. J. (1995). Biological effect monitoring in industrial workers following incidental exposure to high concentrations of ethylene oxide. Mutat. Res. 329(1): 6377.

18. Buck Pumps Instruction Manual. (1995). $2^{\text {nd }}$ edn. Orlando: A.P. Buck, Inc.

19. Eide, M., Martin, M., Motley, K., Plummer, T. and Potter, W. (1993). OSHA: Methods Evaluation Guidelines. U.S.: Department of Labor, pp. 4-15.

20. Cullis, C. F. and Firth, J. G. (1981). Detection \& measurement of hazardous gases. $1^{\text {st }}$ edn. London:Heinemann Educational Books Inc, pp.147-193.

21. National Occupational Health and Safety Commission. (1999). Calculation Of Eight Hour Time-weighted Averages. Australia: Commonwealth of Australia. 
22. Markert, B. (1994). Environmental sampling for Trace Analysis: Organic Gas Sampling. $1^{\text {st }}$ edn. New York: VCH Publishers Inc, pp. 107, 170-172.

23. OSHA Methods Development Team. (1993). Evaluation Guidelines for Air sampling Methods Utilizing Chromatographic Analysis. U.S. Department of Labor, pp. 812.

24. Malaysian Meteorological Service. (1998). Climate of Malaysia. Malaysia: Malaysian Meteorological Service.

25. OSHA Regulations (Standards-29CFR). (1998). Substance safety data sheet for ethylene oxide (non-mandatory)-1910.1047 App. U.S.: Department of Labor.

26. Asakawa, F., Jitsunari, F., Suna, S., Manabe, Y., Fukunaga, I. and Takeda, N. (1993). Measurement of ethylene oxide at a medical sterilization site. Sangyo Igaku. Abstracts 35(5): 413-418. 